\title{
Long-Term Effects of CIPS-based Training Module on Professional Elementary School Teachers
}

\begin{abstract}
Erni Munastiwi*
State Islamic University (UIN) Sunan Kalijaga Yogyakarta, Indonesia

*e-mail: erni.munastiwi@uin-suka.ac.id

Abstract

CIPS-based Training Module has been developed to encourage teachers to improve their personal skills. Hence, the aim of this study is to investigate the long-term effects of the CIPS-based Training Module on the elementary school teachers. This study used the quasi-experimental design that involved 63 elementary school teachers. The teachers were divided into the experimental and control groups to test the objective of this study. The indicators of data analysis used in this study are mean score, standard deviation and independent sample t-test. The results show that there is a significant difference between the experimental and control groups. The experimental group obtained a higher mean score than the control group, which indicates that the CIPS-based Training Module has a positive long-term effect on the elementary school teachers from the experimental group. Hence, it is recommended the CIPS-based Training Module be implemented in the training of teachers, as their thinking and teaching skills will improve, which in turn will benefit the students in attaining high achievement.
\end{abstract}

Keywords: CIPS Model, Training Module

\section{Introduction}

Creativity is an imaginative activity with the mind generating new ideas from the previous knowledge and experiences which can benefit others. According to Qingling Zhang, Pruet Siribanpitak, \& Nuntarat Charoenkul, (2018), creative teachers are able to encourage and motivate the students and eventually the latter will discover their own talents of thinking innovatively and acting independently. Teachers' role is not mere delivering the knowledge but design new and exciting ways of teaching in order to stimulate and develop the students' creative mental power (Robinson, 2011). Problem-solving skills refer to the ability of an individual to search for an efficient and effective solution in order to solve a problem in a timely manner (Karabacak, Nalbant, \& Topçuoğlu, 2015). Lastly, the ability to act or work independently is defined as the skill developed through experiences and interactions with the environment, which helps improve an individual's learning achievements. Independent teachers can evaluate what they have learnt, taking own initiatives to develop procedure that can critically evaluate their teaching process and achieve their envisaged objectives (Hockings, Thomas, Ottaway, \& Jones, 2018).

Development in the education sector in Sebatik Island, Nunukan Regency still shows lag in some aspects such as aspects of classrooms (on wooden poles, wooden floors), other learning facilities, and teachers. The lack of professional teachers is also lacking, this happens because many factors include difficult access to communication and transportation, away from the economic center, away from government centers, residential facilities, and public infrastructure facilities that are still minimal. That causes professional teachers from outside the area to be unwilling to work in border schools (Brata, 2020). In addition to north Kalimantan, in Sintang Regency, West Kalimantan according to UKG tests that have been conducted by elementary school teachers in obtaining grades below government standards. Teachers in Sintang District need training and education to develop teaching competencies, the government as a policy maker must go the extra mile in order to develop the quality of educators, and most importantly teachers in rural and rural areas (Aristo, 2019). While

\footnotetext{
${ }^{*}$ Corresponding author.
}

Received March 01, 2021; Accepted October 31, 2021; Available online December 25, 2021

This is an open access article under the CC BY-SA license. Copyright $(2021$ by Author. Published by Universitas Pendidikan Ganesha 
education in north Kalimantan is still low, infrastructure, lack of educational facilities (Awang Yusuf Aulia Putrayasha, 2017; Pangesti, 2018). extreme topographical conditions in various regions have not fully optimized electronic and communication technology as the basis for the implementation of education in connection with the paradigm and regulations related to it are firmly and clearly set by the government of both regions, provinces and centers (Ali Taufik, 2019). Thus, there needs to be special attention related to institutional and teacher quality improvement in Kalimantan.

Teachers nowadays lack creative thinking, problem-solving skills and ability to work independently as they are too busy focusing on finishing the syllabus within a specified time frame (Alsahou, 2015; Cachia \& Ferrari, 2010). In addition, the learning process in Indonesia only focuses on the cognitive domain; hence the teachers are only concerned with the students' achievements, but not their practical skills (Cotrunnada, Na'Im, \& Sumardi, 2019). For example, when teachers have very few teaching materials in hand, they do not have creative ideas of utilizing them in an interesting way due to the limited teaching hours (Panagiotis Kampylis, Pertti Saariluoma, \& Eleni Berki, 2011). In addition, teachers are unable to function independently to solve their problems when they do not have sufficient knowledge and time to carry out their duty (Hartley \& Plucker, 2014).

Based on exposure to professional competency problems of teachers, there needs to be training for teachers in supporting professional teachers. Previous research has conducted many investigations on the optimization of teacher professionals. however, it still focuses on the final results of implementative processes, such as the implementation of teacher work group activities, PGRI, strengthening teacher work, as optimization of teachers' professional competencies in material mastery, learning, technology use, and writing (E.g Hanifuddin Jamin, 2018; Ibda, 2017; Indah et al., 2020; Sukmawati, 2016). A number of researchers have also researched the implementation of training in optimizing teacher professionals and preparing as mentors for fellow teachers in schools (E.g: Kukk \& Vahter, 2012; Navrátilová, 2017; Ukkonen-Mikkola \& Varpanen, 2020; Worawuth et al., 2014; Zoulikha, 2014). In addition, previous researchers also reviewed a training for teachers of subjects such as English, (Lungu, 2015). Previous researchers also examined the Criteria and problem index and teaching preparation became the basis of teacher professional activities (motivation, practice and theory) (Sultanbek, 2015). But there is still little use of training modules in optimizing teacher professionals. Researchers developed a CIPS-based Training Module developed with the aim of training elementary school teachers on Nunukan Island and Sebatik Island, North Kalimantan, Indonesia. The short term effect was positive and repeated in paying the long term effect in equally implying as it will ensure sustainability of practicing. The CIPS-based Training Module was tested for their long-term effects on the professionalism of the elementary school teachers.

The training module is the combination of two models, which are Creative Problem Solving (CPS) and Independent Learning (IL). The CIPS-based Training Module was developed using the ADDIE model, which includes 5 stages of different tasks: analyze, design, develop, implement and evaluate. Interview sessions with the educational experts were conducted in order to identify the needs of the prospective teaching trainees and the data collected were incorporated into the CIPS-based Training Module. Three (3) main needs were obtained from the interview sessions, which are ability to work independently, problem-solving skills and creative thinking; hence, the training module was developed based on these identified needs. The training module has four (4) main characteristics: creative planning and implementation, innovative and fun learning, ability of teachers to work independently and continual improvement.

The CIPS-based Training Module consists of five (5) stages, which are pre-entering, planning, setting, action and evaluation, and each stage should be implemented accordingly. Stage 1 comprises activities such as setting goals, mapping students and searching for suitable learning resources for the teaching process (Munastiwi, 2015a) Stage 2 is planning; the teachers are ready to develop lesson plans, choose learning media, learning strategies and develop evaluation tools. Stage 3 is the setting of the teaching process, which covers arrangement of facilities, selecting media and establishing a learning environment conducive 
to effective teaching and learning (Munastiwi, 2015b)Stage 4 is Action; the teachers implement the training module according to the 9 steps of the model. Lastly, Stage 5 is Evaluation; the teachers evaluate the whole process of their teaching and obtain feedback to improve their teaching in the future (Munastiwi, 2015b). Thus, this research aims to contribute scientific training on the use of creative, independent, and problem solving (CIPS) modules as one of the strategies for optimizing the professional competence of teachers, especially in border schools in North Kalimantan.

\section{Method}

The quasi-experimental research design was used in this study. Two different groups of elementary school teachers from Nunukan Island and Sebatik Island, North Kalimantan, Indonesia were the subject of this research. The experimental group $(n=33)$ received the CIPS-based Training Module, while the control group $(n=30)$ received the usual teaching process. Both groups took a pre-test before the training was conducted, and a post-test after the CIPS-based training module was completed in 3 months. A questionnaire based on the 5-Point Likert Scale was used as a tool to measure the long-term effects of the CIPS based Training Module on the elementary school teachers. The questionnaire has 92 items and they are grouped under six constructs, namely Teacher Mentoring, Self-actualization, Competency, Creativity, Problem Solving and Independence. A pilot study was conducted before implementing the actual training, the results of which were used to fine-tune the questionnaire so that it would be valid and fit for the real study. The Alpha value of each construct is larger than 0.80 , which indicates that the constructs in the questionnaire are valid and can be used to measure the variables that need to be measured.

\section{Result and Discussion}

\section{Results}

The findings of this study include mean score, standard deviation and independent sample t-test result. Overall, the mean score for the experimental and control group increased after the CIPS-based Training Module was implemented. However, the mean score for each construct of the experimental group is higher than that of the control group. The highest mean score for the experimental group is that of the competency construct (Mean $=4.75, S D=0.20$ ), while the problem-solving construct of the control group has the highest mean score (Mean $=4.54, S D=0.21$ ). The mean scores for each of the constructs are shown in Table 1.

Table 1 Mean Score by Constructs

\begin{tabular}{|c|c|c|c|c|c|}
\hline \multirow[b]{2}{*}{ Construct } & \multirow[b]{2}{*}{ Group } & \multicolumn{2}{|c|}{ Before Training } & \multicolumn{2}{|c|}{ After Training } \\
\hline & & Mean & $\begin{array}{l}\text { Standard } \\
\text { Deviation }\end{array}$ & Mean & $\begin{array}{l}\text { Standard } \\
\text { Deviation }\end{array}$ \\
\hline \multirow{2}{*}{ Teacher Mentoring } & Experiment & 1.97 & 0.33 & 4.64 & 0.22 \\
\hline & Control & 2.18 & 0.75 & 4.51 & 0.19 \\
\hline \multirow{2}{*}{ Self-actualization } & Experiment & 2.31 & 0.18 & 4.70 & 0.17 \\
\hline & Control & 2.15 & 0.76 & 4.37 & 0.16 \\
\hline \multirow{2}{*}{ Competency } & Experiment & 2.50 & 0.13 & 4.75 & 0.20 \\
\hline & Control & 2.20 & 0.84 & 4.44 & 0.26 \\
\hline \multirow{2}{*}{ Creativity } & Experiment & 2.29 & 0.57 & 4.73 & 0.18 \\
\hline & Control & 2.25 & 0.78 & 4.49 & 0.22 \\
\hline \multirow{2}{*}{ Problem Solving } & Experiment & 2.06 & 0.24 & 4.69 & 0.18 \\
\hline & Control & 2.07 & 0.78 & 4.54 & 0.21 \\
\hline \multirow{2}{*}{ Independence } & Experiment & 2.06 & 0.24 & 4.65 & 0.23 \\
\hline & Control & 2.22 & 0.80 & 4.44 & 0.23 \\
\hline
\end{tabular}


Briefly, there is an increase in the mean score of each construct for both groups, but the highest is registered by the experimental group. Hence, the CIPS-based Training Module implemented has a long-term impact on the elementary school teachers from the experimental group. Further analysis conducted on the CIPS-based Training Module shows that there is a positive long-term effect on the elementary school teachers.

After the implementation of the CIPS-based Training Module, the independent sample t-test data and the mean scores obtained were analyzed. The results in Table 2 indicate that there is a significant difference between the experimental group (Mean $=4.64$, $S D=0.22$ ) and the control group (Mean $=4.51, S D=0.19)$ for the construct of Teacher Mentoring, $t(61)=2.529, p=0.014$. Next, the results for the Self-actualizing construct show that there is a significant difference between the experimental group (Mean $=4.70, S D=$ 0.17 ) and the control group (Mean $=4.37, S D=0.16), t(61)=7.793, p=0.000$. Similarly, the results of the Competency construct, show a significant difference between the experimental group (Mean $=4.75, \mathrm{SD}=0.20$ ) and the control group (Mean $=4.44, \mathrm{SD}=0.26), \mathrm{t}(53.28)=$ 5.198, $\mathrm{p}=0.000$.

For the construct of Creativity, the results also show a significant difference between the experimental group (Mean $=4.73, \mathrm{SD}=0.18$ ) and the control group (Min $=4.49, \mathrm{SP}=$ $0.22), t(61)=4.563, p=0.000$. Similarly, the results of the Problem-solving construct show that there is a significant difference between the experimental group (Mean $=4.69, \mathrm{SD}=$ 0.18 ) and control group (Mean $=4.54, S D=0.21$ ), $t(61)=3.050, p=0.003$. Lastly, for the Independence construct, the results show a significant difference between the experimental group (Mean $=4.65, \mathrm{SD}=0.23$ ) and the control group (Mean $=4.44, \mathrm{SD}=0.23), \mathrm{t}(61)=$ $3.467, p=0.001$.

Table 2 Independent-Sample t-test

\begin{tabular}{clcccccc}
\hline & Construct & & \multicolumn{2}{c}{$\begin{array}{c}\text { Levene 's Test } \\
\text { for Equality of } \\
\text { Variances }\end{array}$} & \multicolumn{3}{c}{$\begin{array}{c}\text { t-test for Equality of } \\
\text { Means }\end{array}$} \\
\cline { 3 - 7 } & & $\mathbf{F}$ & $\begin{array}{c}\mathbf{P} \\
\text { value }\end{array}$ & $\mathbf{t}$ & df & $\begin{array}{c}\text { P value } \\
\text { (2-tailed) }\end{array}$ \\
\hline $\begin{array}{c}\text { Teacher } \\
\text { Mentoring } \\
\begin{array}{c}\text { Self- } \\
\text { actualization }\end{array}\end{array}$ & Equal Variances Assumed & 0.000 & 0.997 & 2.529 & 61 & 0.014 \\
$\begin{array}{c}\text { Competency } \\
\text { Ereativity }\end{array}$ & Equal Variances Assumed & 0.004 & 0.947 & 7.793 & 61 & 0.000 \\
$\begin{array}{c}\text { Problem } \\
\text { Solving }\end{array}$ & Equal Variances Assumed & 0.392 & 0.533 & 4.563 & 61 & 0.000 \\
Independence & Equal Variances Assumed & 0.157 & 0.693 & 3.467 & 61 & 0.001 \\
\hline
\end{tabular}

The results show that the implementation of the CIPS-based Training Module has a positive long-term effect on the elementary school teachers in the constructs of Teacher Mentoring, Self-actualization, Competency, Creativity, Problem Solving and Independence. The Competency and Problem Solving constructs obtained the highest scores in the experimental and control groups respectively.

\section{Discussion}

The teachers acquired expertise in problem solving after completing the CIPS-based Training Module. They were able to solve learning problems in class, manage time, and choose suitable strategies for effective knowledge delivery (Dunlosky, Rawson, Marsh, Nathan, \& Willingham, 2013; Hanko, 2016; Shields, 2018). For example, the teachers were able to solve the problem of limited materials in hand for teaching, as they resorted to an 
alternative but suitable way to deliver the lessons. They knew how to motivate their students by making a fair evaluation, and understood their students' desire for learning. Problemsolving skills are an important element of teaching; when the teachers are an expert at solving problems, they can become a good model for their students. The students will then learn to solve various problems when they face them in real-life situations (Owen, 2019).

Creativity is one of the important characteristics of teachers; for example, when the teachers think creatively, they can develop an interesting interactive learning environment for the students. Teachers' creativity is associated with the cognitive process; according to the social cognitive theory, an individual learns directly or indirectly from their social interactions. This theory focuses on the human agency, which has four characteristics: intentionality, forethought, self-reactiveness and self-reflectiveness (Olson \& H., 2014). Teachers who are creative in teaching would pass on this trait to their students in the class. As a result of more creative learning, the students' achievement will also improve as they feel excited to learn more new things. In addition, teachers can also design a creative environment to stir the students' interest of learning, improve the content of teaching materials, and adopt more innovative approaches in teaching (Abidin, Masek, Faiz, \& Sahdan, 2018).

The teachers were able to work independently after going through the CIPS-based Training Module. The teachers took their own initiative to search for teaching materials; they were able to communicate effectively with the students, evaluate objectively, decide wisely on suitable teaching media for independent learning (Sahdan, Masek, \& Zainal Abidin, 2017). When teachers work independently, they are a good model for their students. The students will follow the teachers' example to learn and source for information independently; this habit or characteristic will stay with the students even when they enter the real-life workplace (Balossi \& Hernandez, 2016; Jones, Jones, \& Dexter, 2014). This is an important skill for the students to acquire while they are in the school, and it will remain with them for the rest of their life; when they have problems, they know how to deal with and solve them by themselves as their teachers had implemented the skills in them (Munastiwi, 2015b). The ability to work independently is also an important characteristic of effective teachers; they do not depend on the school management to supply them with everything for teaching. These teachers can teach by using their own strategies and choose the right media for delivering the knowledge to the students (Gipps, C., Hargreaves \& McCallum, 2015).

The elementary school teachers were more competent in their teaching after undergoing the CIPS-based Training Module, because they were trained to follow the instructions effortlessly. The training module introduced five (5) stages of good teaching practices, which are pre-entering, planning, setting, action and evaluation. When the teachers adhered to all the stages of practices, they were competent in their teaching as they followed the steps diligently. For example, a teacher can be sure of achieving the objectives of an activity as they focus on the outcome of each stage. In addition, competent teachers are capable of teaching other subjects apart from their own specialized fields (DarlingHammond, Flook, Cook-Harvey, Barron, \& Osher, 2020; Glaesser, 2019; Liakopoulou, 2011) they know now to adjust the complexity level of teaching according to their students' academic standard, such as the use of an easy-to-understand material and simple language for lower-grade students (Darling-Hammond et al., 2020). Furthermore, competent teachers are able to connect the knowledge delivered in the classroom with the real-world situations, and they often inject innovative elements into their teaching (Foster \& Yaoyuneyong, 2016; Serdyukov, 2017). Lastly, competent teachers find ways to encourage their students to participate actively in the classroom.

Teacher mentoring of the elementary school teachers also improved after they had gone through the training module. They could understand the innovation element in the teacher mentoring model, know the different types of teaching strategies, and realize the importance of mentoring in the teaching process (Spooner-Lane, 2017). When the teachers understood the function of teacher mentoring, they incorporated it in the teaching strategies (Goodwin, Roegman, \& Reagan, 2016). Hence, the teaching yielded better outcome compared with teaching before the implementation of the training module (Callahan, 2016), 
Lastly, the teachers also improved in their level of self-actualization after attending the training module. For instance, teachers were able to make decisions wisely, configure positive environments in the school, as well as produce discipline and instructional manuals. In the teaching process, teachers should know how to make timely and wise decisions, which will influence the students' performance (Veluchamy, Kumar Agarwal, Loganathan, \& Krishnan, 2016). Positive environments are also crucial for the students, through which the teachers can encourage or motivate them to work hard and think smart (Sieberer-Nagler, 2015). A discipline teacher can train their students to be responsible people of good behaviours. After undergoing the training module, the teachers were more assertive and had firmer control over the students, who now were more ready to obey the school rules. When the teachers themselves are disciplined, the students would follow the example and obey the school rules. In short, good and competent teachers will produce responsible students with good performance.

\section{Conclusions and Suggestions}

The study objective is to determine the long-term effects of the CIPS-based Training Module on the teachers' professionalism in the aspects of creativity, problem-solving and ability to work independently. This finding indicates that the CIPS-based Training Module has a positive long-term effect on the elementary school teachers in all the constructs under investigation, namely Teacher Mentoring, Self-Actualization, Competence, Creativity, Problem Solving and Independence. Hence, it is recommended the CIPS-based Training Module be implemented among the teaching staff of higher educational institutions to investigate its effectiveness. This research still has many shortcomings, so that further research is needed. However, this research can contribute to opening up preliminary information for further research.

\section{References}

Abidin, N. A. Z., Masek, A., Faiz, N. S. M., \& Sahdan, S. (2018). Peer-Assessment Unpopular in the Malaysian Higher Education, Why? Advanced Science Letters, 24(11), 8016-8018. https://doi.org/10.1166/asl.2018.12480.

Ali Taufik. (2019). Perspektif Tentang Perkembangan Sistem Pembelajaran Jarak Jauh Di Kabupaten KutaiKartanegara Kalimantan Timur | Jurnal Pendidikan: Riset dan Konseptual. Jurnal Pendidikan: Riset Dan Konseptual, 3(2), 88-98. Retrieved from http://journal.unublitar.ac.id/pendidikan/index.php/Riset_Konseptual/article/view/111.

Alsahou, H. (2015). Teachers' beliefs about creativity and practices for fostering creativity in science classrooms in the State of Kuwait. Retrieved March 23, 2021, from University of Exeter website: https://ore.exeter.ac.uk/repository/handle/10871/19224?show=full.

Aristo, T. J. V. (2019). Analisis permasalahan pemerataan pendidikan di Kabupaten Sintang. Jurnal Akuntabilitas Manajemen Pendidikan, 7(1), 25-34. https://doi.org/10.21831/amp.v7i1.10923.

Awang Yusuf Aulia Putrayasha. (2017). Permasalahan perbatasan indonesia-malaysia: kasus eksodus warga tiga desa di nunukan. Jurnal Analisis Hubungan Internasional, 6 nomor 1, 77-86. Retrieved from http://journal.unair.ac.id/JAHI@permasalahanperbatasan-indonesia-malaysia--kasus-eksodus-warga-tiga-desa-di-nunukan-article11511-media-131-category-8.html.

Balossi, M., \& Hernandez, N. R. (2016). On Teacher Quality in Independent Schools. Peabody Journal of Education, 91(5), 672-690. https://doi.org/10.1080/0161956X.2016.1227192.

Brata, N. T. (2020). Authority and Budget for Education Services in the Border Area: Case Study in Sebatik Island, North Kalimantan. Forum IImu Sosial, 47(1), 19-27. https://doi.org/10.15294/fis.v47i1.24269.

Cachia, R., \& Ferrari, A. (2010). Creativity in Schools: A Survey of Teachers in Europe. https://econpapers.repec.org/RePEc:ipt:iptwpa:jrc59232. 
Callahan, J. (2016). Encouraging Retention of New Teachers through Mentoring Strategies. The Delta Kappa Gamma Bulletin, 83(6). Retrieved from https://www.semanticscholar.org/paper/Encouraging-Retention-of-New-Teachersthrough-Callahan/60827ca4a908d205ccd6720f6fb7e09d2f2757ce.

Cotrunnada, Z. C., Na'Im, M., \& Sumardi. (2019). Comparison of creative and creative capabilities history learning results using the method problem solving and problem based learning. IOP Conference Series: Earth and Environmental Science, 243(1), 012154. https://doi.org/10.1088/1755-1315/243/1/012154.

Darling-Hammond, L., Flook, L., Cook-Harvey, C., Barron, B., \& Osher, D. (2020). Implications for educational practice of the science of learning and development. Applied Developmental Science, 24(2), 97-140. https://doi.org/10.1080/10888691.2018.1537791.

Dunlosky, J., Rawson, K. A., Marsh, E. J., Nathan, M. J., \& Willingham, D. T. (2013, January 1). Improving students' learning with effective learning techniques: Promising directions from cognitive and educational psychology. Psychological Science in the Public Interest, Supplement, Vol. 14, pp. 4-58. https://doi.org/10.1177/1529100612453266.

Foster, J., \& Yaoyuneyong, G. (2016). Teaching innovation: Equipping students to overcome real-world challenges. Higher Education Pedagogies, 1(1), 42-56. https://doi.org/10.1080/23752696.2015.1134195.

Gipps, C., Hargreaves, E., \& McCallum, B. (2015). What makes a good primary school teacher?: Expert classroom strategies. Routledge.

Glaesser, J. (2019). Competence in educational theory and practice: a critical discussion. Oxford Review of Education, 45(1), 70-85. https://doi.org/10.1080/03054985.2018.1493987.

Goodwin, A. L., Roegman, R., \& Reagan, E. M. (2016). Is Experience the Best Teacher? Extensive Clinical Practice and Mentor Teachers' Perspectives on Effective Teaching. Urban Education, 51(10), 1198-1225. https://doi.org/10.1177/0042085915618720.

Hanifuddin Jamin. (2018). Upaya Meningkatkan Kompetensi Profesional Guru . / AT-TA'DIB: Jurnal Ilmiah Prodi Pendidikan Agama Islam (AT-Ta'dib), 10(1). Retrieved from https://ejournal.staindirundeng.ac.id/index.php/tadib/article/view/112.

Hanko, G. (2016). Increasing competence through collaborative problem-solving: Using insight into social and emotional factors in children's learning. David Fulton Publishers.

Hartley, K. A., \& Plucker, J. A. (2014). Teacher Use of Creativity-Enhancing Activities in Chinese and American Elementary Classrooms. Creativity Research Journal, 26(4), 389-399. https://doi.org/10.1080/10400419.2014.961771.

Hockings, C., Thomas, L., Ottaway, J., \& Jones, R. (2018). Independent learning-what we do when you're not there. Teaching in Higher Education, 23(2), 145-161. https://doi.org/10.1080/13562517.2017.1332031.

Ibda, H. (2017). Peningkatan Kompetensi Profesional Guru Sd/Mi Melalui Menulis Di Media. Tarbawi: Jurnal Pendidikan Islam, 14(1). Retrieved from https://ejournal.unisnu.ac.id/JPIT/article/view/610.

Indah, O. :, Utami, H., Hasanah, A., Tarbiyah, F., Keguruan, I., Sunan, U., \& Yogyakarta, K. (2020). Kompetensi Profesional Guru Dalam Penerapan Pembelajaran Tematik Di Sd Negeri Maguwoharjo 1 Yogyakarta. In Pionir: Jurnal Pendidikan (Vol. 8). https://doi.org/10.22373/pjp.v8i2.6232.

Jones, W. M., Jones, W. M., \& Dexter, S. (2014). How Teachers Learn: The Roles of Formal, Informal, and Independent Learning. Educational Technology Research and Development, 62(3), 367-384. https://www.learntechlib.org/p/153779.

Karabacak, K., Nalbant, D., \& Topçuoğlu, P. (2015). Examination of Teacher Candidates' Problem Solving Skills According to Several Variables. Procedia - Social and Behavioral Sciences, 174, 3063-3071. https://doi.org/10.1016/j.sbspro.2015.01.1099.

Kukk, A., \& Vahter, E. (2012). Forming Professional Skills of a Primary School Teacher in the Reflection of Practical and Didactical Teaching. Procedia - Social and Behavioral 
Sciences, 69, 2156-2163. https://doi.org/10.1016/j.sbspro.2012.12.181.

Liakopoulou, M. (2011). The Professional Competence of Teachers: Which qualities, attitudes, skills and knowledge contribute to a teacher's effectiveness? In International Journal of Humanities and Social Science (Vol. 1). http://www.sciepub.com/reference/308480.

Lungu, I. (2015). A New Model of Professionalization of Teachers in Pre-school and Primary School Education. Procedia - Social and Behavioral Sciences, 180, 632-638. https://doi.org/10.1016/j.sbspro.2015.02.171.

Munastiwi, E. (2015a). The Management Model of Vocational Education Quality Assurance Using 'Holistic Skills Education (Holsked).' Procedia - Social and Behavioral Sciences, 204, 218-230. https://doi.org/10.1016/j.sbspro.2015.08.144.

Munastiwi, E. (2015b). The Management Model of Vocational Education Quality Assurance Using 'Holistic Skills Education (Holsked).' Procedia - Social and Behavioral Sciences, 204, 218-230. https://doi.org/10.1016/j.sbspro.2015.08.144.

Navrátilová, H. (2017). Preparing to Become a Teacher Mentor: A Project of Professional Development of Preschool and Primary School Teachers in Czech Republic. Procedia - Social and Behavioral Sciences, 237, 837-842. https://doi.org/10.1016/j.sbspro.2017.02.180.

Olson, B. H., \& H., M. (2014). Theories Of Learning. Jakarta: Kencana.

Owen, C. (2019). Problem-based learning. In Learning and Teaching in Higher Education. Edward Elgar Publishing.

Panagiotis Kampylis, Pertti Saariluoma, \& Eleni Berki. (2011). Fostering Creative Thinking What do Primary Teachers Recommend? | Kampylis | Hellenic Journal of Music, Education and Culture. Hellenic Journal of Music, Education, and Culture, 2(1), 4664. Retrieved from http://hejmec.eu/journal/index.php/HeJMEC/article/view/11.

Pangesti, I. (2018). Kemiskinan, Pendidikan, Kewiraswastaan Dan Pengangguran Di Daerah Propisnsi Kalimantan Utara (Kaltara). Jurnal Pengembangan Wiraswasta, 20(1), 73. https://doi.org/10.33370/jpw.v20i1.177.

Qingling Zhang, Pruet Siribanpitak, \& Nuntarat Charoenkul. (2018). Creative leadership strategies for primary school principals to promote teachers' creativity in Guangxi, China | Kasetsart Journal of Social Sciences. Kasetsart Journalof Social Sciences, 41(2), 275-281. Retrieved from https://so04.tcithaijo.org/index.php/kjss/article/view/232606.

Sahdan, S., Masek, A., \& Zainal Abidin, N. A. (2017). Student's Readiness on Self-regulated Learning Implementation for 21st Century Learning Approaches. Ertanika Journal of Social Sciences \& Humanities , 25s, 195-203. Retrieved from https://scholar.google.com/citations?user=TPTq1B4AAAAJ\&hl=en.

Serdyukov, P. (2017). Innovation in education: what works, what doesn't, and what to do about it? Journal of Research in Innovative Teaching \& Learning, 10(1), 4-33. https://doi.org/10.1108/jrit-10-2016-0007.

Shields, M. (2018). What Really Works in Special and Inclusive Education: Using EvidenceBased Teaching Strategies. Teach Journal of Christian Education, 12(1). Retrieved from https://research.avondale.edu.au/teach/vol12/iss1/16.

Sieberer-Nagler, K. (2015). Effective Classroom-Management \& Positive Teaching. English Language Teaching, 9(1), 163. https://doi.org/10.5539/elt.v9n1p163.

Spooner-Lane, R. (2017). Mentoring beginning teachers in primary schools: research review. Professional Development in Education, 43(2), 253-273. https://doi.org/10.1080/19415257.2016.1148624.

Sukmawati, S. (2016). Profesionalisme Guru Sekolah Dasar. Jurnal Visi IImu Pendidikan, 7(2). https://doi.org/10.26418/jvip.v7i2.17055.

Sultanbek, M. (2015). Pedagogical Problems of Primary School Teachers' Professional Preparation. Procedia - Social and Behavioral Sciences, 197, 2490-2493. https://doi.org/10.1016/j.sbspro.2015.07.320.

Ukkonen-Mikkola, T., \& Varpanen, J. (2020). Integrated initial and continuing training as a way of developing the professional agency of teachers and student teachers. 
$\begin{array}{llll}\text { Teaching and Teacher Education, } 103189 . & \text { 96, }\end{array}$ https://doi.org/10.1016/j.tate.2020.103189.

Veluchamy, R., Kumar Agarwal, K., Loganathan, M., \& Krishnan, A. R. (2016). Perception on the Role of Teachers in Managing Talents of Generation Z Students An Ideal Teacher. Indian Journal of Science and Technology, 9(36), 1-7. https://doi.org/10.17485/ijst/2016/v9i36/102604.

Worawuth, P., Prayuth, C., Kanokorn, S., Udomporn, K., Chadchawarn, A., \& Wilawan, P. (2014). Integrated Learning Teacher Professional Development in Primary Schools. Procedia - Social and Behavioral Sciences, 112, 775-780. https://doi.org/10.1016/j.sbspro.2014.01.1229.

Zoulikha, T.-M. (2014). Training of the Primary School Teacher and his Professional Domain Field Study. Procedia - Social and Behavioral Sciences, 112, 1187-1195. https://doi.org/10.1016/j.sbspro.2014.01.1283. 